Sadat City University

Faculty of Education

Dep. of Curriculum

The Effects of Using Reciprocal Teaching on Developing EFL Secondary School Second Graders' Oral Proficiency

A Thesis submitted in partial fulfillment of the requirements for obtaining the Master of Arts degree in Education

(EFL Curriculum and Instruction)

By

Ahmad Fawzy Muhammad Said

English language Teacher

2021 


\section{The Problem and its Significance}

\section{Introduction}

English language has a unique place among globe languages as it is the language of science, technology, business, trade and political or diplomatic talks. Also, it is the language of communication between individuals and nations. Meaningful communication is at the heart of social life. In order to communicate efficiently, one should have mastery in the productive skills of English language, either in oral or written form .

Speaking is the way through which students can interact with others to accomplish specific purposes or to express their views, thoughts, and intentions.. Furthermore, in most situations or places, speaking is the most utilized skill of language skills. It is supported by Rivers (1981) who says speaking is used twice as much in our conversation as reading and writing. According to Hedge (2000: 261) speaking is "a skill by which people are judged while first impressions are being formed ".

\section{Relationship of Listening and Speaking}

The value of devoting high-time class time in order to improve oral effectiveness is something for foreign language teachers should be taken into account. However it is not possible to listen to yourself. Listening without intercourse applies to tasks like listening to radio or official speeches where the transmission of data is only from the speaker to the listener in one direction. On the contrary, reciprocal listening alludes to the listening activities in which there is a chance for the listener to communicate with the speaker and to discuss the matter of speech.

\section{Difficulties of Speaking in Foreign Language Learning}

A foreign language speaker's capacity is different from a language expertise. Echevarria et al (2008), point out that in the learning phase the gap between understanding how to do things is necessary. Speaking skills are often a concern for EFL students.

Reciprocal teaching is an educational activity in which the teacher and the student share discussions on a specific activity, subject or text between themselves and the students (Zaitoun, 2003). According to Asiri \& Alshehri (2020), 
activity focused on conversations between teachers and students or between students themselves in order for the divided into parts to be fully understood. This is introduced by summarizing each segment after reading it, asking questions about difficulties, and eventually anticipating ideas that could be introduced later on. Brown and Palincsar (1989) define reciprocal teaching as an interactive conversation between the teacher and students, which assists students in developing their reading via scaffold instruction of strategies of fostering and monitoring comprehension. Greenway (2002) sees that reciprocal teaching aims to assist beginner readers to become proficient by instructing them the methods used by skilled readers to analyze text meanings.

\section{Context of the problem}

During his teaching to the second year secondary students using the traditional techniques of teaching speaking skill, such as asking questions, assigning reports to be presented by students before the class, asking students to read texts, the researcher noticed that these students had a noticeable difficulty.

in speaking fluently and accurately, they had lack of vocabulary, they were not able to correctly pronounce the words, and they were not able to use the grammatical structures properly as well.

\section{Statement of the Problem:}

As mentioned above the problem of the study can be recognized in the poor mastery of the necessary speech skills by secondary students in the second year, which should be improved. This might be attributed to the conventional methods of teaching adopted by most teachers of English language in the secondary stage to realize the objectives. Thus, the current study used a reciprocal teaching strategy as an attempt to enhance the students' speaking skills. In other words, the study tried to address the following main question:

What is The Effect of Using Reciprocal Teaching Strategy on Developing EFL Second year Secondary Students' Speaking Skills?

This question could be branched into the following sub-questions:

1- What are the speaking skills necessary for second year secondary students?

2- What is the effectiveness of using reciprocal teaching strategy in developing second year secondary students' speaking skills? 


\section{Objectives}

This study seeks to provide a number of objectives. They are:

- To examine whether there is a significant difference for the experimental group in the speaking post- test owing to the use of reciprocal teaching strategy.

- To investigate the effects of using reciprocal teaching strategy on the speaking skill of second year secondary students.

\section{Significance}

The current study may be significant for students, teachers, and curriculum designers. For students, it may assist them to be conscious of their vital roles in the learning process and they should be active not passive learners. Also, it may enhance the students' speaking skill and motivate their desire to speak English continuously to achieve high progress in communication .

For teachers, the study may help them in simplifying their role during teaching and the learning process changes from teacher-centered to student-centered .

For Curriculum designers, the study may draw their attention to the benefits of using reciprocal teaching strategy in teaching the skills and aspects of English language .

\section{Hypotheses}

The following hypotheses will be tested ;

- There would be a statistically significant difference between the mean scores obtained by students of the experimental group and those of the control group on the overall speaking post- test in favor of the experimental group.

- There would be a statistically significant difference between the mean scores obtained by students of the experimental group and those of control group on each speaking sub-skill post- test in favor of the experimental group.

- The effectiveness of using reciprocal teaching strategy in developing second year secondary students' speaking skills. 


\section{Delimitations}

- A program in using a reciprocal teaching strategy to enhance students' Speaking skills (comprehension - fluency -vocabulary - pronunciation - Grammar).

- Teaching units (10 \& 11) from the textbook Hello 7.

- Sixty second year secondary students enrolled in El Qawmya Secondary School, 6 October City, Egypt.

- The training program was implemented in the second semester of the academic year 2019/2020 at El Qawmya Secondary School, 6 October City, Egypt.

\section{Definition of Terms}

\section{Reciprocal teaching}

Hacker and Tenent (2002: 669) define reciprocal teaching as "an instructional procedure in which small groups of students learn to improve their reading comprehension through scaffolded instruction of comprehension-monitoring strategies".

Operationally, it is a teaching strategy used to encourage students to speak English and enhance their speaking skill throughout the utilization of its four steps which are predicting, questioning, clarifying, and summarizing, and their involvement in the learning process .

\section{Oral Proficiency}

According to Omaggio (1986) cited in Wichadee (2017), oral proficiency alludes to the ability to communicate verbally in a functional and accurate way in a target language. A person with a high degree in oral proficiency is able to apply the linguistic knowledge to new situations or contexts.

Operationally, it is the capability of expressing ideas, feelings, and opinions about certain topics orally in a fluent and accurate way.

\section{Study Organization}

The study consists of five chapters. In chapter one the researcher gives an introduction to speaking, listening and speaking relationship, difficulties of speaking skills, and reciprocal teaching strategy. The researcher then explains the 
research problem, objectives, questions and its hypotheses proceed. Finally the researcher outlines the significance, the limitations of the research and the definition of key words.

Chapter two is dedicated to the literature review of research on to the effect of reciprocal teaching strategy on the students' speaking proficiency.

Chapter three outlines the design of the research and the methodologies used for the study. It contains detailed information on participants, the instruments used.

to collect data and finally the techniques of data analysis. The results and analysis of the data collected during the speaking test are presented in Chapter Four. The conclusion, the study recommendations and the suggestions for further research are discussed in Chapter five.

\section{Chapter II Literature Review}

This chapter discusses the origins of reciprocal teaching, techniques and features, principles of reciprocal teaching strategy. Also it discusses the roles of teachers and students in this strategy. Moreover, it gives a view on speaking skill, its functions, elements, teaching, and its relationship with reciprocal teaching.

\section{- Reciprocal Teaching Strategy}

\section{- Origins of Reciprocal Teaching}

Reciprocal Teaching is a strategy developed in the USA by Annemarie Palincsar and Ann Brown in 1984 for teaching reading comprehension. Palincsar (1986) states that the goal of Palincsar and Brown was to assist teachers in teaching reading effectively and in encouraging students who were seen as low or at-risk comprehends. Similarly, Allen (2003) states that reciprocal teaching aims at using discussion to develop students' reading comprehension skills and enhance their self-regulatory and motivation. Palincsar \& Klenk (1991) postulate that reading is encouraged when teachers and students change the roles in leading the discussion of the text to meet common understanding through applying the four strategies of reciprocal teaching: predicting, clarifying, questioning, summarizing. 
- Reciprocal Teaching Principles:

According to Palincsar, Ransom, and Derber (1989) there are four principles underlying reciprocal teaching:

- Reciprocal teaching is designed to enhance reading comprehension by providing students with the appropriate techniques to track understanding and context.

- Teachers and students share responsibilities for reading strategies acquisition. The teacher steadily transfers roles onto the students after taking the main responsibility for teaching these techniques.

- Each student will take part in the talks. The teacher gives a hand to student when required to encourage them to participate.

- The teacher regularly attempts to transform the control of the dialogues to the students.

\section{Reciprocal Teaching Features:}

Hartman (2001) mentions that reciprocal teaching features are dialogue (social interaction), teacher's scaffolding, and four main strategies.

- Dialogue :

Dialogue is seen as the heart of reciprocal teaching. Guided dialogues in reciprocal teaching lessons can help students who have never aced reading to meaningfully learn from the text.

- Teacher's Scaffolding:

The idea of scaffolding is based on Vygotsky's social constructivism learning. Vygotsky (1978), states that each mental feature in an infant's development first occurs in cooperation with an expert or adult. This cooperation takes place in the proximal development area, which lies between what a child himself can do and what they require help to do.

- The four major strategies:

- Questioning :

Teachers teach students how to construct and pose questions about reading, 
problem. When reading, questions are typically easier if they concentrate on main text information - not irrelevant information.

\section{- Clarifying:}

It includes comprehension monitoring; confirming and determining whether anything is ambiguous, and clarification; taking measures to achieve understanding.

\section{- Predicting:}

It includes discovering structure and hints about what may come next during reading a text. Predictions trigger awareness and build perceptions, making facts more important and easier to recall. It allows students to mediate about what they already know and compare that to what they are now studying or doing.

\section{- Summarizing:}

It is to mention the most necessary ideas with a few words. Successful summaries do not involve details or unnecessary information. The most basic processes in summarizing include choosing major ideas and very relevant details, and narrowing it down to its core.

\section{- Reciprocal Teaching Educational and Active Panorama}

Reciprocal teaching strategy has been commonly utilized by teachers at all levels of learning because it is a rich strategy-based method. It has been tried by teachers who wanted to develop the language proficiency of their students as well as their performance and achievement.

- Teacher's role in Reciprocal Teaching:

Hacker et al (2002) illustrate that the teacher begins to teach every strategy as the sage on the stage, and finishes as the guide of the side. The teacher must model these strategies for the students proficiently and after that gradually disappear and allow students to take charge of their learning .

- Students' role in Reciprocal Teaching:

Mukkattu (2012: 4) shows the role of students in reciprocal teaching as follows:

The Leader: 
* Informs students what they read.

* Asks every student after reading each section of the text to do the process.

* Makes sure that all students are joining in.

\section{Questioning:}

The students' main goal is to start to start isolating a key point, to check that they understand this by creating a response, and to check the group's understanding.

Students come up with higher-level questions aimed at deeper comprehension .

\section{Clarifying:}

The students' main goal is to enhance comprehension, and to demonstrate to others how to clarify meaning.

- Students assist each other to clarify the words that are difficult to understand.

- May clarify what they did to assist them comprehend the text.

\section{Predicting:}

The students' main goal is to make the text meaningful and to sustain an aim for reading using prior knowledge and common sense. The student does the following:

- $\quad$ Makes use of what was read or hints from the explanations to predict what may happen next.

\section{Summarizing:}

The students' main goal is to recognize and incorporate the text major points to make meaning.

- $\quad$ Students give a brief account of the incidents after reading a text.

- $\quad$ Students may use these sentences to begin with: The most essential ideas are..., The major idea of the text is..., This section was about..., First..., Next..., Then . 


\section{- Speaking Skill}

What is speaking?

Previous research adopted two primary approaches to defining speaking; they are bottom-up approach and top down approach.

- Nature of speaking skill:

Although there are some similarities between speaking and other language skills, it has special nature. Understanding the distinctions between and speaking and writing assists in planning to teach.

- Functions of Speaking:

Functions of the speaking skill should be scrutinized and considered. These functions pose some difficulties and recognize specific guidelines for comprehending this skill and thus design educational activities to effectively prepare students to communicate in real-life situations.

- Aim of speaking:

The aim of speaking was argued to be either transactional or interactional. Actually, there are specific distinctions between the transactional discourse and interactional discourse.

- Elements of Speaking

Speaking is an essential skill for students who want to master English communication. Five aspects have a significant effect on ability of speaking, they are:

a. Vocabulary

b. Grammar

c. Fluency

d. Pronunciation

e. Comprehension 


\section{- Types of Classroom Speaking Performance}

According to Brown (1994), various types of speaking students can perform in the classroom; the types are:

a- Imitative

b- Intensive

c- Responsive

d- Transactional (dialogue)

e- Interpersonal (dialogue).

f- Extensive (monologue).

\section{- Teaching Speaking:}

Harmer (2007) provides three reasons for teaching speaking in the classroom. First, the activities utilized in teaching speaking help students practice real-life speech simply and safely. Second, speaking tasks need to be done with familiar language to students, providing teachers and students with feedback on their progress and language challenges. Finally, the students' language becomes automated and eloquent because of their practice and use of the different language forms stored in their brains. This eventually turns students into autonomous users of language.

\section{- Assessment of Speaking}

Two methods of assessing speaking skills; they are holistic scoring and analytic scoring (Sarwar et al, 2014). In contrast, the analytic scoring attempts to isolate main performance aspects and evaluate each one of them separately and independently on its subscale; therefore, it focuses on distinct performance characteristics, typically incorporating scores on the independent sub-scales to create a whole score for speaking (Taylor \& Galaczi, 2011).

The current research adopted the analytic scoring in assessing speaking test as it examines different elements of the test individually, scoring each element independently. It used the SOLOM rating scale to assess students' speaking on comprehension, vocabulary, grammar, pronunciation, and fluency. 


\section{- Reciprocal Teaching and Speaking}

In applying reciprocal strategy, teacher distributes the topic to students to discuss it. Because the process of reciprocal strategy requires students to make a prediction to what the topic will be about, the student attempts to correlate their prior knowledge to the information existed in the topic. The predicting strategy enriches students' vocabulary.

\section{Commentary}

Teaching speaking to secondary stage students is crucial to reach the most identified goal in learning a language which is communication. Because cooperative learning and interactive activities are social in nature, the utilization of cooperative learning would be a natural selection for reinforcing those interactive activities. Reciprocal teaching, in particular, as defined by Palincsar and Brown (1986) is a cooperative strategy that provides itself a platform for communication teaching.

All the above-mentioned literature studies emphasized the effectiveness of using reciprocal teaching strategy in improving students' skills of reading comprehension. The current study is similar to these studies in the research design method and in showing the efficacy of the reciprocal teaching strategy.

The next chapter will present the methodology of the study .

\section{Chapter Three: Material and Method}

This chapter deals with the material and method that the researcher used in the current study. It includes the design and implementation of the study instruments

- The following items are discussed in this chapter:

1- The research design.

2- The participants.

3- The instruments which include;

- a speaking pre- post-test.

- $\quad$ SOLOM rubric for scoring the speaking test 
4- The training program.

5- Implementation of the instruments.

6- The procedures.

\section{- The research design.}

The present study adopted the quasi-experimental design .The treatment group was trained and instructed using reciprocal teaching strategy in improving speaking skill through the program of the study. A variety of activities, strategies, presentation methods were introduced. The non-treatment group did not receive such training and followed the regular methods of teaching speaking.

\section{- Variables of the study}

A - The independent variable: reciprocal teaching strategy .

B - The dependent variable: speaking skill.

\section{- The participants}

The students chosen for the present study were sixty second year secondary students enrolled at El Qawmya language school, 6 October City, Egypt during the second semester of the academic year 2019/2020. The two groups were assigned to an experimental group, which consisted of thirty students, and a control group, which consisted of thirty students. The treatment group students were taught using reciprocal teaching strategy whereas the non-treatment group students were taught using the regular method.

\section{- The instruments}

A speaking pre- post test.

Objectives of the test

A speaking test was used as a pre and post-test. The speaking pre-test was used to ensure that the two groups were at the same level of English speaking before beginning the treatment, and thus the improvement achieved by the experimental group could be due to the training program they received. As for the post-test, it was used to investigate the effectiveness of using reciprocal teaching strategy in improving speaking skills of that group (treatment group). 


\section{- Test Description}

The researcher designed the test according to a table of specifications that showed the percentage, number of questions, and test scores devoted to each skills and sub-skills. The test consisted of two parts. In the first part, students were asked three questions. In the second part, students were asked two questions (See appendix three)

\section{- Test Validity}

To make certain of the test validity, a jury comprised five EFL specialists read the test to judge its items in terms of the following points:

a) Appropriateness of the test items to students' linguistic level.

b) Clarity and linguistic correctness of the test items.

c) Ability of the test items to measure the specified skills.

d) Suitability of the test items to the overall aim of the test.

\section{- Test Reliability}

In order to measure the reliability of the test, it was administered to a randomly selected sample of 30 second year secondary students. The pilot study was conducted 15 days before implementing the treatment. Reliability of the test determined by using Cronbach's Alpha was found to be (0.88), which is an acceptable level of reliability.

\section{- Test administration}

During the pilot study, it was rated that a period of 20 minutes would supply adequate time for students to read the tasks and fill in the test .

- Rubric for scoring the speaking test

The researcher adopted SOLOM (Student Oral Language Observation Matrix) analytic rubric that was validated by the same jury who validated the speaking test. As for scoring reliability, it was ensured by training three raters to use the rubric in marking the students' answers. Each rater marked the students' answers on his own. The average of the three raters' marks was taken. 
- The training program.

Aims of the training program :

The program aimed at aiding students to use reciprocal teaching strategy to enhance their speaking skills.

Steps of the program design:

In order to design the program, the researcher ;

1- Reviewed literature related to methods of teaching, strategies, and activities in teaching and learning vocabulary.

2- Investigated EFL methodology books, surfing the internet, perusing the book of Hello (7) and consulting TEFL specialists.

3- built up a frame of the program comprising general aims of the unit, behavioral objectives of lessons, content areas, activities, and methods of evaluation.

4- built up a training program comprising a teacher's book and a student's book.

5-submitted the training program to a set of TEFL specialists for ensuring its validity and suitability. The jury was asked to judge the training program for:

- $\quad$ Suitability of the program aims to the study sample.

- Relatedness of the program content to its aims.

- $\quad$ Suitability of the program's content, activities, methods of teaching and evaluation techniques for students' linguistic level.

- Suitability of the activities, methods of teaching and evaluation techniques for the aims of the program as a whole and the specific objectives of lessons.

\section{- The content of the program}

The program comprised two major sections:

\section{A. Teacher's Guidebook:}

It included a detailed description of what the teacher had to do in each teaching session. The teacher's guidebook consisted of two units divided into lessons that

مجلة " التربية في القرن ا Y للارسات التربوية و النفسية" ـ كلية التربية - جامعة مدينة السادات

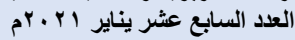
matched student's guidebook . 


\section{B. Student's Guidebook:}

It included the content and objectives presented to the sample of the study. For selecting the topics included in the program, the researcher reviewed literature related to strategies of reciprocal teaching to teach speaking (see appendix 2).

Teaching activities:

Activities of the program were chosen to match and suit its aims. They depended on whole class discussion, viewing videos, viewing pictures, note-taking, group work, pair work, and individual work .

\section{- Evaluation techniques}

The training program was performed through various teaching techniques which needed various evaluation techniques .Examples of these techniques are:

- $\quad$ Self and peer-editing

- $\quad$ Teacher editing

- Formative evaluation items(during and following each lesson) to provide continuous feedback to both the teacher and students to assess students' performance for the ultimate goal of reinforcing strength and dealing with limitations.

- Implementation of the instruments

Pre-implementation of the instruments:

\section{A-The pre-post speaking test:}

The pre-post speaking test was administered to the participants of the study before the inception of implementing the program in order to obtain data about students' speaking level. Students' responses were corrected and data was derived, recorded, and statistically analyzed to specify the speaking skills of the study participants before introducing the training program. The following table shows the results of the pre- test in overall speaking.

- Implementation of the training program:

It started on February 10, 2020 and ended on March 15, 2020. 
- Post-implementation of the instruments:

A-The pre-post speaking test:

The pre-post speaking test was administered to the participants of the study after the implementation of the study program in order to examine whether the training program had any significant effect on the students' speaking skills. Students' responses were scored and data was derived, recorded, and statistically analyzed to record any development transpiring in the students' speaking skills owing to the training program.

\section{- The procedures:}

The researcher followed these procedures for the purpose of collecting data for the study:

1) Selecting the topics from the book of Hello 7.

2) Reviewing related literature.

3) Establishing the suitability and validity of the training program by a jury.

4) Designing the training program in using reciprocal teaching strategy.

5) Designing a pre-post speaking test.

6) Establishing the validity and reliability of the pre-post speaking test.

7) Getting the approvals to conduct the study.

8) Pre-testing the control group and the experimental group to measure their speaking skills.

9) Implementing the training program was from February 10, 2020 to March 15, 2020.

10) Post- testing the control group and the experimental group to measure their speaking skills.

11) Training three raters on how to use the rubric for marking the students' speaking test.

12) Analyzing students' scores on the instruments statistically using "t-test."

13) Reporting and discussing results.

14) Offering recommendation and suggestions for further research.

\section{- Conclusion}

This chapter dealt with the designing and implementation of the study instruments. It was fundamentally concerned with dealing with the material, method, and procedures followed for 
implementing the study. The following chapter will deal with the findings of the study and their discussions.

\section{Chapter Four: Findings and discussion}

The present study aimed at investigating the effect of using reciprocal teaching strategy to improve second year secondary students' speaking skills. Therefore, the aim of this chapter is to present the data analysis, findings and discuss the results of the study based on the study questions and hypotheses.

\section{Statistical Analysis}

In the present study, the t-test was utilized in discussing the results of study instruments implementation.

\section{- Findings}

The treatment of the study lasted for six weeks. At the end of the treatment, the speaking skill pre-post test was administered to the experimental and control groups. Results of the students were analyzed and compared using the Statistical Package for Social Sciences (SPSS) to calculate the t-test value that explains the differences between mean scores of the study participants in the post administration of the speaking test.

\section{- The first hypothesis of the study}

The first hypothesis predicted that the experimental group would outperform the control group in post-performance on overall speaking test. Analysis showed that the experimental group achieved significantly higher than the control group on the overall speaking test as t- value 10.89 is significant at (0.05) level.

\section{- The second hypothesis of the study.}

The second hypothesis predicted that the experimental group would outperform the control group in post-performance on each speaking sub-skill. Analysis showed that the experimental group achieved significantly higher than the control group on each speaking sub-skill test as t- value is significant at (0.05) level. 


\section{- The third hypothesis of the study.}

The third hypothesis predicted that the effectiveness of using reciprocal teaching strategy in improving second year secondary students' speaking skills .

\section{- Discussion of Findings}

The findings displayed above reveal that students' speaking skills developed after implementing the program of the study. This significant development asserts the effectiveness of the treatment in improving students' performance speaking skills.

The results of the study evinced that there was a statistically significant difference $(t=10.89)$ and in favor of the treatment group students. This result was in line with the findings of Clark (2003), Al-Adgham (2004), Abd Al-Wahab (2005),Ahmad (2008), Abdul-Majeed (2013), and Al-Harby (2016).

The development of the treatment group students' the overall speaking performance (the first hypothesis), and the speaking sub-skills performance (the second hypothesis) could be attributed to many factors.

\section{Conclusion}

This chapter dealt with the findings of the study and their discussions. The following chapter will deal with the summary of the study and pedagogical implications.

\section{Chapter Five: Conclusions, Recommendations and Further Research}

This chapter presents a summary of the research. It discusses in brief the research problem, questions, methodology, and the findings of the study. Conclusions, recommendations and future research are also presented.

\section{- Summary}

Achieving success in learning a foreign language greatly depends on student's ability to converse in that language. Thus, speaking is considered as the main skill to be developed since it is essential for showing the language proficiency. 


\section{- The Findings}

The following findings were reached:

1. There was a statistically significant difference (favoring the experimental group) between the mean scores obtained by subjects of the experimental group and those of the control group in overall speaking post-test.

2. There was a statistically significant (favoring the experimental group) between the mean scores obtained by subjects of the experimental group and those of the control group in each speaking sub-skill.

3. The differences indicate the effectiveness of the reciprocal teaching strategy in developing those students' speaking skills.

In light of the above findings, it can be concluded that the reciprocal teaching strategy has positive effects on the students' speaking skills. Thus the main aim of the study was achieved proving its effectiveness.

\section{- Recommendations:}

In light of the current study findings, the following recommendations are cited.

1. Using reciprocal teaching strategy has to be a conspicuous part of the EFL speaking teaching and learning at different learning stages.

2. Students should be given speaking activities that aim at encouraging them to speak without speaking apprehension.

3. Teachers should exploit training opportunities to increase their knowledge and expertise in teaching speaking via reciprocal teaching strategy.

4. Speaking sub-skills should be scored according to rubrics and which list the fundamental criteria for evaluating these skills and students should be informed these criteria.

\section{- The limitations}

The researcher encountered some difficulties throughout the research, for example;

1- The students' speaking apprehension as they are sure of making mistakes when speaking English. 
2- $\quad$ Scarcity of studies related to speaking teaching through using reciprocal teaching strategy.

3- Results cannot be generalized.

\section{- Suggestions for further research}

In light of the current study findings, the researcher suggests the following further studies:

1) The current study could be replicated using other subjects from university students.

2) The current study could be replicated using other subjects from different stages of education.

3) Future research is required to investigate the effectiveness of using reciprocal teaching strategy in developing writing skills.

4) Future research is required to investigate the effectiveness of using reciprocal teaching strategy in developing listening skills.

\section{References}

Abdul-Majeed, M. R. (2013). The Effect of Using Reciprocal Teaching on Improving College Students' Achievement in Reading Comprehension. Journal of College of Education for Women, 24(3), 900-916.

case for balanced teaching (2nd ed.). New York: Guilford

case for balanced teaching (2nd ed.). New York: Guilford

case for balanced teaching (2nd ed.). New York: Guilford

Celce, M., \& McIntosh, M. L. (1987), Teaching English as a Second or Foreign Language, (Los Angeles: New Bury House University of California.

Echevarria, J. Vogt, M.E. \& Short, DJ. (2008). Making Content Comprehensible For English Learners: The Siop Model. New York: Pearson Education.

Ellis, R. \& Barkhuizen,G.( 2005). Analysing learner language. Oxford: OUP.

Fulcher, G. (2003). Testing second language speaking. Pearson Education . 
Galloway, C. A. (2001). Vygotsky's learning theory. In M. Orey (Ed.), Emerging perspectives on learning, teaching, and technology. Available Website: http://projects.coe.uga.edu/epltt/index.php?title=Vygotsky\%27s_constructivism

Hacker, D. J., \&Tenent, A. (2002).Implementing reciprocal teaching in the classroom: Overcoming obstacles and making modifications. Journal of Educational Psychology, 94(4), 699.

Hussein, K. (1986). Classroom Processes and Developing Communicative Competence in English among Secondary School Students. Unpublished Ph.D. Dissertation. Faculty of Education, Zagazig University.

Khalil, A. H., El-Nagar, B. E. \& Awad, M. A. (2019).The effect of brain-based learning on developing some speaking skills of Egyptian EFL Secondary School Students. International Journal of Environmental and Science Education, 14(3), 103-116.

Lestari, A. A. (2016). The effectiveness of reciprocal teaching method embedding critical thinking towards MIA second graders' reading comprehension of MAN 1 Kendari. Journal of Teaching of English, 4(1), 1-15.

Malock, B. (2002). Scaffolding student talk: One teacher's role in literature discussion groups. Reading Research Quarterly, 37 (1), 94-112 .

Nazara, S. (2011).Students' perception on EFL speaking skill development. JET (Journal of English Teaching), 1(1), 28-43.

Nunan, D. (1990). Second Language Teaching and Learning. Boston: Heinle \& Heinle Publisher.

Oczkus, L. (2003). Reciprocal teaching at work: Strategies for improving reading comprehension. Newark, DE: International Reading Association.

Palincsar, A. S. (1986). The role of dialogue in providing scaffolded instruction. Educational Psychologist, 21, 73-98.

Palincsar, A. S., \& Brown, A. L. (1985). Reciprocal teaching of comprehension strategies: A natural history of one program for enhancing learning (Tech. Rep. No. 334). Urbana- Champaign: University of Illinois, Center for the Study of Reading. 
Richards, J. C. (2008). Teaching listening and speaking: From theory to practice. Cambridge: Cambridge University Press.

Richards. J. (1990). The Language Teaching Matrix. Cambridge: Cambridge University Press.

Sunda, E. N. L. (2018). The implementation of reciprocal teaching technique to improve students' speaking skills: A case study in the 9th Grade Student of 9C at MTsN 1 Sumedang (Doctoral dissertation, UIN Sunan Gunung Djati Bandung).

Ur, P. (2000). A course in Language Teaching: Practice and Theory. Cambridge: Cambridge University Press.

Vygotsky, L. (1978). Mind in society: The development of higher psychological processes. Cambridge, MA: Harvard University Press.

Wichadee, S. (2017).A development of the blended learning model using Edmodo for maximizing students' oral proficiency and motivation. International Journal of Emerging Technologies in Learning (iJET), 12(02), 137-154.The learner's ability to express himself/herself orally, coherently, fluently and appropriately in a given meaningful context.

Yusuf, M. M. A. (2015). The Effectiveness of Using Reciprocal Teaching Strategies for Developing Secondary Students' Listening Comprehension Skills (Doctoral dissertation).

Zaitoun, H. (2003) Strategies of Teaching: A Modern View of Learning/Teaching Methods . Cairo, AlamAlKo. 